University of South Carolina

Scholar Commons

$10-2014$

\title{
Modernizing Social Inclusion: A Look at John Carlo Bertot's Contribution
}

Kim M. Thompson

University of South Carolina - Columbia, kthompso@mailbox.sc.edu

Follow this and additional works at: https://scholarcommons.sc.edu/libsci_facpub

Part of the Library and Information Science Commons

\section{Publication Info}

Published in The Library Quarterly, Volume 84, Issue 4, 2014, pages 460-466.

(c) Library Quarterly, 2014, University of Chicago Press

Thompson, Kim M. (2014). Modernizing Social Inclusion: A Look at John Carlo Bertot's Contribution. Library Quarterly, 84(4), 460-466. http://dx.doi.org/10.1086/677781

This Article is brought to you by the Information Science, School of at Scholar Commons. It has been accepted for inclusion in Faculty Publications by an authorized administrator of Scholar Commons. For more information, please contactdigres@mailbox.sc.edu. 


\title{
Modernizing Social Inclusion: A Look at John Carlo Bertot's Contribution
}

\author{
Kim M. Thompson
}

n 1994, the Clinton administration had very recently set goals for widespread public access

to the Internet by connecting "every classroom, every clinic, every library, and every hospital in America” by the year 2000 (Clinton 1994, 4). The Executive Branch specified its focus on promoting universal access and ensuring public access to government information online and provision of "better social equity for the public" (McClure, Bertot, and Zweizig 1994, ii). It was in this year that Charles R. McClure, John Carlo Bertot, and Douglas L. Zweizig presented the first ever Public Libraries and the Internet report, addressing the report to then President William J. Clinton, with support from the US National Commission on Libraries and Information Science. The Internet and the World Wide Web were quite new to the general public at this time, and the Public Libraries and the Internet report shows tremendous foresight in identifying the role public libraries could and would take in providing the American public with Internet access, training, and socialization. The report notes that, at that time, 20.9 percent of public libraries had Internet connectivity. It also reports that those connected public libraries tended to be in larger communities and that only some offered public Internet access. For the most part, these public libraries were using the Internet for administrative tasks, reference services, and some government information services, not providing direct access to patrons; rather, the Internet was an information tool to be used by information professionals. Total spending for Internet connections and services was estimated to be $\$ 14,398,550$, a very low figure, leading the report's authors to express that it was an amount "insufficient and incompatible with the vision expressed by [the Clinton Administration's] goals." The report recommends that "policymakers will need greater public debate on the degree to which federal funding should be provided to public libraries to contribute toward accomplishing these policy goals" (McClure et al. 1994, 41).

In this 1994 report, the authors tie Internet access to principles of social inclusion, exploring differences between access in rural and urban areas, focusing not only on Internet access but also on Internet use and services, and discussing how the study's findings might be used to influence policy decisions for funding and other government support. Fortunately, this

Library Quarterly: Information, Community, Policy, vol. 84, no. 4, pp. 460-466. (c) 2014 by The University of Chicago. All rights reserved. $0024-2519 / 2014 / 8404-0007 \$ 10.00$

460 
1994 report was but the first of a now two-decade longitudinal study of public libraries and the Internet. All subsequent Public Libraries and the Internet studies have been led by Bertot, providing us with a body of literature that charts public library Internet adoption. Bertot has worked with a series of colleagues, research assistants, and funding agencies to regularly and consistently provide the key data sets by which we can now easily chart the adoption of the Internet in public libraries in the United States and measure public library Internet adoption. Bertot and his teams have tailored the studies to include data collection related to issues of universal service, public access to government information, infrastructural issues and challenges, evaluation of service quality, and the extent to which the public Internet access points and library services provided by public libraries help users access and use information.

These data collection efforts are indeed efforts. Having worked with Bertot and McClure on the 2002 survey myself, cold-calling library directors by phone in order to ensure a statistically viable number of completed surveys, I greatly admire Bertot for his resilience in continuing the study year after year, seeking funding, training research assistants, revising the survey and interview instruments, updating the samples, and querying the data in new and interesting ways with each iteration. What is of particular interest to me as I review Bertot's work, including his work not directly related to the Public Library and the Internet studies, is how he has contributed to what I think of as a modernization of the concept of social inclusiona modernization that incorporates elements of digital inclusion, community outreach, civic participation, and evaluation of services in order to tailor social inclusion community by community.

The term "social inclusion" is frequently used as short hand for a range of issues on the social agenda. Social and cultural capital, social equity, social networks, civic engagement, and digital inclusion are often used as cognates in scholarly and policy literature related to discussion of social inclusion. Terms that are closely related, but from an opposing view, include "social inequalities," "poverty," “information poverty," “educational inequality," “social exclusion,” "disadvantage," "alienation," and "marginalization," "disenfranchisement," "disability," and "minority." At its most basic level, the concept of social inclusion "goes beyond economics and the reduction of poverty and inequality ... social inclusion is about opportunity; it represents the combined factors necessary for an individual to enjoy a safe, productive life as a fully integrated member of society" (Americas Quarterly 2013, 47). Although only a few of Bertot's papers specifically discuss social inclusion by name, his work to date contributes to the social inclusion literature and has significantly impacted the field of library and information studies. His publications - both those he has written alone and those he has completed with colleaguesare cited in many hundreds of articles, proceedings, editorials, book chapters, and other works on both a national and international level. In particular, his work provides a view of how social inclusion can be and is improved through evaluation and measurement, focus on universal service and digital inclusion, and provision of information. 


\section{Improving Social Inclusion through Evaluation and Measurement}

The ongoing Public Libraries and the Internet reports are the most outstanding example of Bertot's leadership in advocating measurement and evaluation that allows interested parties to observe how changes in policies, funding, and/or practice can and do either advance or thwart social inclusion. The regular measurement of public library Internet access and service by Bertot and his team has not only provided good examples of these evaluation practices, but their published data have also provided benchmarks by which we can identify barriers to social inclusion as they arise, such as funding cuts to public libraries as institutions providing outreach services. For example, although the 2011-12 report indicates that public libraries have maximized their public access computer and Internet service (100 percent of public libraries now offer these services), the study results "demonstrate that libraries provide and enhance their public access services where possible, but have experienced reductions in staff, hours, and budgets. Thus public libraries are increasingly unable to fully meet demand as they are increasingly challenged to build digitally inclusive communities through digital literacy, employment, e-government, and Internet-enabled services and resources" (Bertot, McDermott, et al. 2012, 2), potentially reducing the ability of public libraries to offer the services individuals need in the community for maximum social inclusion.

Bertot has published numerous articles, chapters, proceedings, and editorials based on the survey and interview data collected with his Public Libraries and the Internet studies, but he has also provided instruction and advocacy for evaluative methods such as web server log analysis (Bertot et al. 1997); usability, functionality, and accessibility (Bertot et al. 2003; Bertot and Jaeger 2006, 2008a; Bertot, Snead, et al. 2006; Bertot, Berube, et al. 2012); outcomes assessment (Bertot 2003a, 2006; Bertot and McClure 2003); surveys (Bertot and McClure 1996b; Bertot and Jaeger 2008b); and other measures to assess service quality (Bertot and McClure 1996a; Bertot 2001; Bertot, McClure, and Davis 2004; Bertot and Snead 2004).

\section{Improving Social Inclusion through Universal Service}

The democratic concept of universal service is that government can partner with the private sector to create an information infrastructure that serves all Americans universally (i.e., equitably) and thus ensure an informed public. Postal service, radio, telephony, television and cable services, and now Internet services have received federal support to move toward ensuring that urban and rural, rich and poor, young and old, individuals with and without disabilities, and so forth, have reasonable access to the needed information services and technologies of the day. Bertot and his collaborators have provided a steady call for public libraries to take an active role in supporting government in the provision of universal service, particularly in terms of digital inclusion. Digital inclusion is an aspect of social inclusion wherein equitable access to digital technology and services is provided, allowing individuals access to information and services available online (Thompson et al., forthcoming). Bertot's work highlights the impact of free public access computers and Internet connections on the community (Bertot and McClure 
1997; Bertot, McClure, and Jaeger 2008; Bertot 2009), outreach to underserved groups (McClure and Bertot 1997; Bertot 2000), the information literacy needed to access and understand information and the information infrastructure (Bertot, McClure, and Owens 1999; Bertot 2003b), and even the global implications of universal service (Bertot, McClure, and Owens 1999; Bertot 2003c). His writings not only consistently provide answers to the "why is this important" questions related to universal access; they also beautifully provide "how to" instruction for practitioners, policy makers, and researchers to advance universal service and digital inclusion.

\section{Improving Social Inclusion through Provision of the Information}

As noted above, the underlying goal of universal service is an informed populace for democratic participation. It is not enough to simply provide information; in order for citizens to have the information they need for social and civic inclusion, they need "the right information at the right time, in the right place, in the right form, and of sufficient completeness and quality to perform the current activity" (Jones 2004, 2). This is perhaps even more important when dealing with government information and e-governance. Bertot's work underscores the need for government transparency (Bertot, Jaeger, and Grimes 2010; Bertot, Jaeger, Munson, et al. 2010; Jaeger and Bertot 2010) and a keen focus on use and user-centered design of e-government platforms and services (Bertot and Jaeger 2008a). Bertot's writings identify policy issues that might lessen the potential of public libraries to provide socially inclusive information services, such as drawing our attention to the way in which federal agencies rely on public and other libraries to support e-government services and provide users with government information, even when federal funding is not provided to support these library services (Bertot, Jaeger, et al. 2006; Bertot et al. 2009; Bertot 2010; Jaeger, Bertot, and Shuler 2010; Shuler, Jaeger, and Bertot 2010; Jaeger et al. 2012). Bertot has coauthored a number of articles that identify and analyze current information policy, making the policies accessible to information professionals and researchers and encouraging public libraries and other public organizations to improve and extend the information services they provide (McClure, Moen, and Bertot 1999; Bertot and Moen 2000; Jaeger, Bertot, and McClure 2003, 2004; Jaeger et al. 2004; Jaeger, McClure, and Bertot 2005; Jaeger, Bertot, et al. 2006; Bertot et al. 2009; Bertot, Jaeger, and Hansen 2012). Thus, his works not only draw attention to the need for information agencies to provide timely and useful information to the public but also provide instruction on how the offered information might be used to improve both information services and social inclusion.

\section{Conclusion}

Perhaps the most important lesson observed through a review of Bertot's work on social inclusion is to stay current. His work has kept pace with policy changes, advances in digital technology and connection speeds, Web 2.0 and social media, and other physical and social 
factors affecting the information worlds in which we reside. This is reflected in his Public Library and the Internet studies, as well as his other writings. The services and practices that support social inclusion are ever-evolving as economies, political climates, technologies, communities, and societies change. This constant change reinforces the importance of Bertot's approach to improving social inclusion through evaluation and measurement; a focus on elements that support social inclusion in the present, such as digital inclusion and universal service; and provision of the information needed to allow full social participation.

\section{References}

Americas Quarterly. 2013. “The Social Inclusion Index 2013.” Americas Quarterly, Summer. http://americasquarterly .org/charticles/Social_Inclusion_Index_2013/S I_INDEX_FINAL-7-29-13.pdf.

Bertot, John Carlo. 200o. "Universal Service in the Networked Environment: The Education Rate (E-rate) Debate." Lournal of Academic Librarianship 26 (1): 45-8.

Bertot, John Carlo. 2001. "Measuring Service Quality in the Networked Environment: Approaches and Considerations." Library Trends 49 (4): 758-75.

Bertot, John Carlo. 2003a. “An Action Plan for Outcomes Assessment in Your Library.” Libraru Ouarterly $73(3): 344-46$.

Bertot, John Carlo. 2003b. "The Multiple Dimensions of the Digital Divide: More Than the Technology 'Haves' and 'Have Nots'." Government Information Ouarterly 20 (2): 185-91.

Bertot, John Carlo. 2003c. "World Libraries on the Information Superhighway: Internet-Based Library Services.” Library Trends 52 (2): 209-27.

Bertot, John Carlo. 2006. "Outcomes-Based Evaluation in Public Libraries: From Online Instruction to Practice." Libraru Ouarterly 76 (2): 241-45.

Bertot, John Carlo. 2009. "Public Access Technologies in Public Libraries: Effects and Implications." Information Technology and Libraries 28 (2): 81-92.

Bertot, John Carlo. 2010. "Community-Based E-government: Libraries as E-government Partners and Providers." Electronic Government 6228:121-31.

Bertot, John Carlo, Katy Berube, Peter Devereaux, Kerry Dhakal, Stephen Powers, and Jennie Ray. 2012. “Assessing the Usability of WorldCat Local: Findings and Considerations." Libraru Ouarterly 82 (2): 207-21.

Bertot, John Carlo, and Paul T. Jaeger. 2006. "User-Centered E-Government: Challenges and Benefits for Government Web Sites." Government Information Ouarterly 23 (2): 163-68.

Bertot, John Carlo, and Paul T. Jaeger. 2008a. “The E-government Paradox: Better Customer Service Doesn't Necessarily Cost Less." Government Information Ouarterly 25 (2): 149-54.

Bertot, John Carlo, and Paul T. Jaeger. 2008b. "Survey Research and Libraries: Not Necessarily Like in the Textbooks." Libraru Ouarterly 78 (1): 99-105.

Bertot, John Carlo, Paul T. Jaeger, and Derek Hansen. 2012. "The Impact of Policies on Government Social Media Usage: Issues, Challenges, and Recommendations." Government Information Ouarterly 82 (2): 294-95.

Bertot, John Carlo, Paul T. Jaeger, and Justin M. Grimes. 2010. "Using ICTs to Create a Culture of Transparency: E-government and Social Media as Openness and Anti-corruption Tools for Societies." Government Information Ouarterly 27 (3): 264-71. 
Bertot, John Carlo, Paul T. Jaeger, Lesley A. Langa, and Charles R. McClure. 2006. "Drafted: I Want You to Deliver E-government." Library Journal 131 (13): 34-37.

Bertot, John Carlo, Paul T. Jaeger, Sean Munson, and Tom Glaisyer. 2010. "Social Media Technology and Government Transparency." Computer 43 (11): 53-59.

Bertot, John Carlo, Paul T. Jaeger, Shannon N. Simmons, Justin M. Grimes, and John A. Shuler. 2009. "Reconciling Government Documents and E-Government: Government Information in Policy, Librarianship, and Education." Government Information Ouarterly 26 (3): 433-36.

Bertot, John Carlo, and Charles R. McClure. 1996a. "Developing Assessment Techniques for Statewide Electronic Networks." Proceedings of the 59th ASIS Annual Meeting 33:110-17.

Bertot, John Carlo, and Charles R. McClure. 1996b. "Electronic Surveys: Methodological Implications for Using the World Wide Web to Collect Survey Data." Proceedings of the 59th ASIS Annual Meeting 33:173-85.

Bertot, John Carlo, and Charles R. McClure. 1997. "Impacts of Public Access to the Internet through Pennsylvania Public Libraries." Information Technology and Libraries 16 (4): 151-64.

Bertot, John Carlo, and Charles R. McClure. 2003. "Outcomes Assessment in the Networked Environment: Research Questions, Issues, Considerations, and Moving Forward." Library Trends 51 (4): 590-613.

Bertot, John Carlo, Charles R. McClure, and Denise M. Davis. 2004. "Capture Usage with E-metrics." Library Journal 129 (8): 30-32.

Bertot, John Carlo, Charles R. McClure, and Kimberly A. Owens. 1999. "Universal Service in a Global Networked Environment: Selected Issues and Possible Approaches." Government Information Ouarterly 16 (4): $309-27$.

Bertot, John Carlo, Charles R. McClure, and Paul T. Jaeger. 2008. "The Impacts of Free Public Internet Access on Public Library Patrons and Communities." Libraru Ouarterly 78 (3): 285-301.

Bertot, John Carlo, Charles R. McClure, William E. Moen, and Jeffrey Rubin. 1997. "Web Usage Statistics: Measurement Issues and Analytical Techniques." Government Information Ouarterly 13 (4): 373-95.

Bertot, John Carlo, Charles R. McClure, Kim M. Thompson, Paul T. Jaeger, and Lesley A. Langa. 2003. Florida Electronic Library: Pilot Project Functionality Assessment for the Florida Division of Library Services. Tallahassee, FL: Information Use Management and Policy Institute.

Bertot, John Carlo, Abigail McDermott, Ruth Lincoln, Brian Real, and Kaitlin Peterson. 2012. Public Library Funding and Technology Access Survey: Survey Findings and Results. College Park, MD: Information Policy and Access Center.

Bertot, John Carlo, and William E. Moen. 2000. "FirstGov.gov/or/net/com: Issues and Considerations." Journal of Academic Librarianship 26 (6): 422-26.

Bertot, John Carlo, and John T. Snead. 2004. "Selecting Evaluation Approaches for a Networked Environment." In Planning and Evaluating Library Networked Services and Resources, edited by John Carlo Bertot and Denise M. Davis. Westport, CT: Libraries Unlimited.

Bertot, John Carlo, John T. Snead, Paul T. Jaeger, and Charles R. McClure. 2006. "Functionality, Usability, and Accessibility: Iterative User-Centered Assessment Strategies for Digital Libraries.” Performance Measurements and Metrics 7 (1): 17-28.

Clinton, William J. 1994. "State of the Union Address." Washington, DC, January 25.

Jaeger, Paul T., and John Carlo Bertot. 2010. "Transparence and Technological Change: Ensuring Equal and Sustained Public Access to Government Information." Government Information Ouarterly 27 (4): 371-76. Jaeger, Paul T., John Carlo Bertot, and Charles R. McClure. 2003. "The Impact of the USA PATRIOT Act on Collection and Analysis of Personal Information under the Foreign Intelligence Surveillance Act." Government Information Ouarterly 20 (3): 295-314. 
Jaeger, Paul T., John Carlo Bertot, and Charles R. McClure. 2004. “The Effects of the Children's Internet Protection Act (CIPA) in Public Libraries and Its Implications for Research: A Statistical, Policy, and Legal Analysis." Lournal of the American Society for Information Science and Technology 55 (13): 1131-39.

Jaeger, Paul T., John Carlo Bertot, Charles R. McClure, and Lesley A. Langa. 2006. "The Policy Implications of Internet Connectivity in Public Libraries." Government Information Ouarterly 23 (1): 123-41.

Jaeger, Paul T., John Carlo Bertot, and John A. Shuler. 2010. "The Federal Depository Library Program (FDLP), Academic Libraries, and Access to Government Information." Iournal of Academic Librarianship $36(6): 469-78$.

Jaeger, Paul T., Natalie N. Greene, John Carlo Bertot, Natalie Perkins, and Emily E. Wahl. 2012. "The Coevolution of E-government and Public Libraries: Technologies, Access, Education, and Partnerships." Library and Information Science Research 34 (4): 271-81.

Jaeger, Paul T., Charles R. McClure, and John Carlo Bertot. 2005. "The E-Rate Program and Libraries and Library Consortia, 2000-2004: Trends and Issues." Information Technologu and Libraries 24 (2): 57-67.

Jaeger, Paul T., Charles R. McClure, John Carlo Bertot, and John T. Snead. 2004. “The USA PATRIOT Act, the Foreign Surveillance Act, and Information Policy Research in Libraries: Issues, Impacts, and Questions for Libraries and Researchers." Library Ouarterly 74 (2): 99-121.

Jones, William. 2004. "Finders Keepers? The Present and Future Perfect in Support of Personal Information Management.” First Monday 9 (3). DOI:http://dx.doi.org/10.5210/fm.v9i3.1123.

McClure, Charles R., and John Carlo Bertot. 1997. “Creating a Future for Public Libraries: Diverse Strategies for a Diverse Nation.” Library Trends 46 (1): 36-51.

McClure, Charles R., John Carlo Bertot, and Douglas L. Zweizig. 1994. Public Libraries and the Internet: Study Results, Policy Issues, and Recommendations. Washington, DC: National Commission on Libraries and Information Science.

McClure, Charles R., William E. Moen, and John Carlo Bertot. 1999. "Descriptive Assessment of Information Policy Initiatives: The Government Information Locator Service (GILS) as an Example." Journal of the Association for Information Science and Technology 50 (4): 314-30.

Shuler, John A., Paul T. Jaeger, and John Carlo Bertot. 2010. "Implications of Harmonizing the Future of the Federal Depository Library Program within E-government Principles and Policies.” Government Information Ouarterly 27 (1): 9-16.

Thompson, Kim M., Paul T. Jaeger, Natalie Greene Taylor, Mega Subramaniam, and John Carlo Bertot. Forthcoming. Digital Literacy and Digital Inclusion: Information Policy and the Public Library. Lanham, MD: Scarecrow.

Kim M. Thompson: lecturer in the School of Information Studies, Charles Sturt University. Thompson's research and teaching specialize in the social study of information, including information studies within the cultural context, international perspectives on information access and information poverty, and examination of the links between information access and social inclusion. Implications of Thompson's research extend to improving information services in libraries and other information organizations, as well as providing greater understanding of information issues on an international scale. E-mail: kithompson@csu.edu.au. 